УДК 57.013

\title{
Effect of Drying Mode of Bacterial Biomass \\ on the Effectiveness of Extraction \\ and Physicochemical Properties \\ of the Product (Polymer)
}

\author{
Alexey V. Demidenkoa, \\ Olga N. Vinogradova ${ }^{a, b *}$ and Evgeniy G. Kiselev ${ }^{a, b}$ \\ ${ }^{a}$ Siberian Federal University \\ 79 Svobodny, Krasnoyarsk, 660041, Russia \\ ${ }^{b}$ Institute of Biophysics SB RAS \\ 50/50 Akademgorodok, Krasnoyarsk, 660036, Russia
}

Received 12.12.2015, received in revised form 03.02.2016, accepted 06.06.2016

Comparative study of different drying modes of bacterial biomass of Cupriavidus eutrophus B10646 was conducted. Different modes differently affect the yield of the product (polymer) and its physicochemical properties (molecular weight distribution and temperature characteristics). High temperatures caused the polymer degradation and decrease of its molecular weight. Using freeze drying allows to obtain friable biomass with an extended surface which is favorable for extraction process and to preserve the molecular weight characteristics of the polymer.

Keywords: polyhydroxyalkanoates, PHA extraction, bacterial biomass, freeze drying.

DOI: $10.17516 / 1997-1389-2016-9-2-180-189$.

(c) Siberian Federal University. All rights reserved

* Corresponding author E-mail address: olgav88@mail.ru 


\title{
Влияние режима высушивания \\ бактериальной биомассы на полноту экстракции \\ и физико-химические свойства продукта (полимера)
}

\author{
А.В. Демиденко \\ О.Н. Виноградова ${ }^{a, \sigma}$, Е.Г. Киселев ${ }^{a, \sigma}$ \\ ${ }^{a}$ Сибирский федеральныий университет \\ Россия, 660041, Красноярск, пр. Свободный, 79 \\ ${ }^{6}$ Институт биофизики СО РАН \\ Россия, 660036, Красноярск, Академгородок, 50/50
}

\begin{abstract}
Проведено сравнительное исследование различных режимов высушивания биомассы бактерий Cupriavidus eutrophus B10646. Показано, что различные режимы оказывают влияние на выход конечного продукта (полимера) и его физико-химические свойства (молекулярно-массовые и температурные характеристики). Использование высоких температур приводит к деградации полимера и снижению его молекулярной массы. Применение сублимаџионной сушки позволяет получить рыхлую биомассу с довольно развитой поверхностью, что благоприятно сказывается на прочессе экстракциии и не приводит к изменению молекулярно-массовых характеристик полимера.
\end{abstract}

Ключевые слова: полигидроксиалканоаты, ПГА, экстракиия, бактериальная биомасса, сублимационная сушка.

\section{Введение}

В стоимости производства полигидроксиалканоатов (ПГА) существенная доля затрат приходится на их выделение из клеточной биомассы. Полнота выделения, в свою очередь, зависит от режима обработки биомассы и способа экстракции. Большинство процессов выделения этих полимеров из клеток базируется на экстракции органическими галогенсодержащими растворителями (хлороформ, дихлорметан, дихлорэтан), использование которых позволяет получать не только полимер, но и имеет перспективу получения дополнительных продуктов в виде липидов и жирных кислот (Choi, Lee, 1999a, 1999b). Прямая экстракция из сырой биомассы хлорорганическими растворителями сопряжена с рядом трудностей: вода, содержащаяся в клетках, препятствует проникновению растворителя и образует эмульсии (Thakor et al., 2005), а липиды, переходящие вместе с полимером в экстракт, снижают ассоциативные свойства растворителя (Mantelatto et al., 2013).

Вода является основным количественным компонентом любого биологического объекта. Заключенная в клетках, она не только среда для протекания ферментативных реакций, но и структурный элемент мембран и биополимеров, выступает в роли мембранообразующего фактора (Харчук, 2005). По современным представлениям, возникновение мембранных структур - бимолекулярного липидного слоя со строго ориентированными молекулами фосфолипидов - возможно 
только в водной среде благодаря гидрофобным взаимодействиям. Содержание воды в мембранах может достигать $50 \%$, при этом до $30 \%$ находится в прочносвязанной форме (Potts, 1994). Мембрану представляют как вязкую гетерогенную двумерную жидкость, характеризующуюся высокой динамичностью (Culic-Krzywicki, 1975; Бергельсон, 1975). Процесс обезвоживания микроорганизмов всегда связан с определёнными изменениями, на популяционном уровне наблюдается уменьшение числа жизнеспособных клеток; на клеточном уровне обнаруживаются изменения на поверхности клетки, в ядре и мембранных структурах (Krallish et al., 1986; Beker et al., 1984).

Во время сушки в результате действия протеолитических ферментов происходит денатурация белков. При нагревании скорость ферментативных реакций увеличивается, повышение температуры на $10{ }^{\circ} \mathrm{C}$ приводит к её двукратному увеличению; и, наоборот, при охлаждении скорость ферментативных процессов снижается. Нагревание выше определённой температуры приводит к полной инактивации ферментов. Обычно ферменты инактивируются за 5 мин при температуре $75{ }^{\circ} \mathrm{C}$. Существуют значительные отклонения, так, некоторые ферменты инактивируются при температуре $40{ }^{\circ} \mathrm{C}$, в то время как другие не разрушаются и при $100{ }^{\circ} \mathrm{C}$. Кроме температуры на инактивацию ферментов оказывает влияние продолжительность воздействия (Харчук, 2005). Механизм устойчивости к высушиванию основан на стабилизации двойного фосфолипидного слоя мембран гликолипидами и ненасыщенными жирными кислотами под влиянием водного стресса (Singh et al., 2002). Липиды - эффективные источники сохранения энергии, играющие важную роль структурных элементов клеточных мембран. Около 1 \% липидов образует сложные соеди- нения с белком - липопротеины, являющиеся основными структурными элементами клетки (Beker et al., 1984). Во время высушивания бактериальной биомассы липиды в присутствии кислорода подвергаются окислению (Perelman et al., 1998).

В биотехнологии имеют дело с живыми микроорганизмами, а в ряде случаев для продукта требуется сохранение питательной ценности, биологической активности, жизнеспособности (Войнов и др., 2009), следовательно, сушильные технологии, применяемые в производстве, должны соответствовать ряду технико-экономических параметров, таких как минимальная энергоемкость, максимальная однородность сушки, минимальное время, минимальное влияние на конечный продукт. Данные параметры обеспечиваются пониманием базовых физических процессов, приводящих к обезвоживанию продуктов, соответствующих им технологий высушивания за счет оборудования, на котором указанные процессы и технологии могут быть реализованы (Кунилова, 2008).

Ранее проведённые исследования показали, что использование водных растворов детергентов позволяет успешно выделять полимер из сырой биомассы, однако данный метод не даёт возможности получить продукт высокой чистоты, поэтому на второй стадии приходилось проводить очистку продукта с помощью органических растворителей (дихлорметана и гексана). Данный метод связан с вовлечением в процесс больших количеств воды и образованием большого объёма сточных вод, загрязнённых детергентом и клеточными структурами, а также не позволяет отказаться от органических растворителей, которые необходимо регенерировать (Киселев, Демиденко, 2014).

В свою очередь, биомасса кроме ПГА является источником липидов и жирных кислот, 
которые могут быть выделены на стадии экстракции органическими растворителями $(\mathrm{Li}$ et al., 2014). Содержащаяся в биомассе вода является препятствием для проникновения растворителя в клетку и приводит к снижению эффективности процесса экстракции. Таким образом, при использовании для выделения полимера (готового продукта) органических растворителей, не смешивающихся с водой, вопросы высушивания биомассы в производстве стоят очень остро.

В целом анализ литературы показывает необходимость оптимизации методов сушки бактериальной биомассы как необходимое условие повышения эффективности процесса экстракции органическими растворителями и снижения стоимости полимера как конечного продукта биотехнологического процесса. Это определило цель настоящей работы, направленной на исследование влияния температуры в процессе сушки на выход и физикохимические свойства готового продукта (полимера 3-гидроксибутирата).

\section{Материалы и методы}

В работе использованы образцы бактериальной биомассы Cupriavidus eutrophus В10646 в виде сырой пасты влажностью 50-60\%, полученной центрифугированием бактериальной суспензии при 6000 об/мин в течение 15 мин (Beckman-Coulter, Avanti, США).

При высокотемпературном суховоздушном высушивании бактериальной биомассы (сушильный шкаф Memmert UN 55, Германия) исследованы температуры 60 и $105{ }^{\circ} \mathrm{C}$. Сублимационное высушивание реализовали в установке IlshinBioBase (Корея); замороженную до температуры минус $40{ }^{\circ} \mathrm{C}$ биомассу высушивали нагреванием до $+20{ }^{\circ} \mathrm{C}$ при давлении в камере 40 Па. Показателем эффективности сушки служила остаточная влажность биомассы. Биомассу, высушенную в сушильном шкафу, измельчали в ступке.

Экстракцию полимера проводили в два этапа. На первом этапе этанолом удаляли липиды и жирные кислоты, на втором-трёхкратно экстрагировали полимер дихлорметаном (Li et al., 2014). Полученные дихлорметановые экстракты объединяли, упаривали в два раза на роторном испарителе R/210 V Buchi (Швейцария). Далее проводили осаждение полимера гексаном в соотношении 1:2 (Киселев, Демиденко, 2014). Содержание полимера в исходной биомассе и наличие нежелательных примесей (прежде всего липидов и жирных кислот) в полимере, т.е. чистоту полимера контролировали с использованием газового хроматографа с хромато-масс-спектрометром (6890/5975C, Agilent Technologies, США) по общепринятым методикам после метанолиза проб (Zhila et al., 2015).

Количество веществ, извлекаемых этанолом, определяли путём отбора аликвоты в количестве 10 мл и высушиванием в выпарных чашках. Выход экстрактивных веществ, извлекаемых этанолом (в процентах от сухой биомассы) рассчитывали по формуле

$$
X=\frac{V *\left(m_{\mathrm{a}}-m_{\mathrm{\Psi}}\right) * 10}{m_{\mathrm{H}}}
$$

где $\mathrm{V}$ - объём полученного экстракта, мл; $\mathrm{m}_{\mathrm{a}}$ и $\mathrm{m}_{4}$ - масса чашки с навеской и исходной чашки соответственно, г; $\mathrm{m}_{\text {н }}$ - масса сухой биомассы, взятой для экстракции, г.

Молекулярную массу полимера определяли с использованием системы гельпроникающей хроматографии Agilent 1200 c набором полистироловых стандартов (Sigma, США). Находили значение средневесовой, среднечисловой молекулярной массы и полидисперсности $\left(\mathrm{M}_{\mathrm{в}}, \mathrm{M}_{q}\right.$, ПД); температурные характеристики - методом дифференциально-сканирующей калори- 
метрии на приборе DSC 1 (Mettler Tolledo, Швейцария). Эксперименты проведены в трех аналитических повторностях. Математическую обработку экспериментальных данных проводили стандартными методами; определяли средние значения результатов; рассчитывали отклонения от среднего значения для каждого результата; дисперсию, стандартное отклонение отдельного результата и стандартное отклонение среднего результата. Проверку надежности полученных результатов определяли по критерию Стьюдента при избранной доверительной вероятности $\alpha=0,95$. Полученные результаты проверяли по одному из вышеописанных способов (по критериям максимального отклонения, Стьюдента) на наличие грубых ошибок. После исключения грубых ошибок производили повторную обработку результатов (Ашмарин и др., 1971). Для решения поставленных задач использовали программy MS OfficeExcel 2007 с встроенным пакетом анализа данных.

\section{Результаты и обсуждение}

Кривые сушки бактериальной биомассы, высушенной с использованием различных температурных режимов, представлены на рис. 1. Наиболее быстро высушивание происходило при $105{ }^{\circ} \mathrm{C}$ (рис. 1а), спустя 16 ч высушивания образцы не содержали влаги. При $60{ }^{\circ} \mathrm{C}$ время сушки увеличилось до 60 ч (рис. 1б), при этом в первые 8 ч активного испарения влаги не происходило, температура биомассы повышалась, однако влажность снижалась незначительно. Далее скорость сушки возрастала, достигая к концу периода прогрева максимальной величины; процесс высушивания продолжался около 30 ч. Длительность процесса влияла на остаточную влажность биомассы, которая варьировала от 6 до 8-10\%.
Длительность сублимационной сушки составила 48 ч, полученный образец биомассы содержал остаточную влагу в количестве не выше $0,5 \%$. На кривой сушки отображены все этапы процесса (рис. 1в). Первый этап - заморозка - характеризуется пологим участком кривой и занимает около 5 ч. Далее следует активное удаление свободной влаги и длится этот процесс около 22 ч. На заключительном этапе в течение 21 ч происходит удаление молекулярно связанной воды, участок кривой, характеризующий данный этап, приобретает более пологий вид.

Сравнительная оценка эффективности экстракции полимера из биомассы, высушенной при различных режимах и температуре, проведена с использованием органических растворителей. На первом этапе образцы экстрагировали 96\%-ным этанолом, в результате в экстракт переходят липиды, жирные кислоты, далее проводили экстракцию полимера дихлорметаном (табл. 1).

При использовании сырой биомассы выделено менее 80 \% полимера от его исходного содержания в биомассе. Неполнота экстракции связана с тем, что предварительная экстракция спиртом не приводит к полному разрушению клеточной стенки, кроме того, следует учитывать наличие воды в системе, которая приводит к разбавлению растворителя и стабилизации клеточных мембран. В данной системе вода, до $20 \%$ которой находится в клетках бактерий в связанном состоянии, проявляет мембранообразующие свойства и препятствует проникновению растворителя в клетку (Харчук, 2005).

Наибольший выход полимера получен из образцов биомассы, высушенной сублимационно и при температуре $60{ }^{\circ} \mathrm{C}$, соответственно 95,5 и 85,3 \%. Можно предположить, что в результате сушки и экстракции этанолом негативное воздействие на кле- 


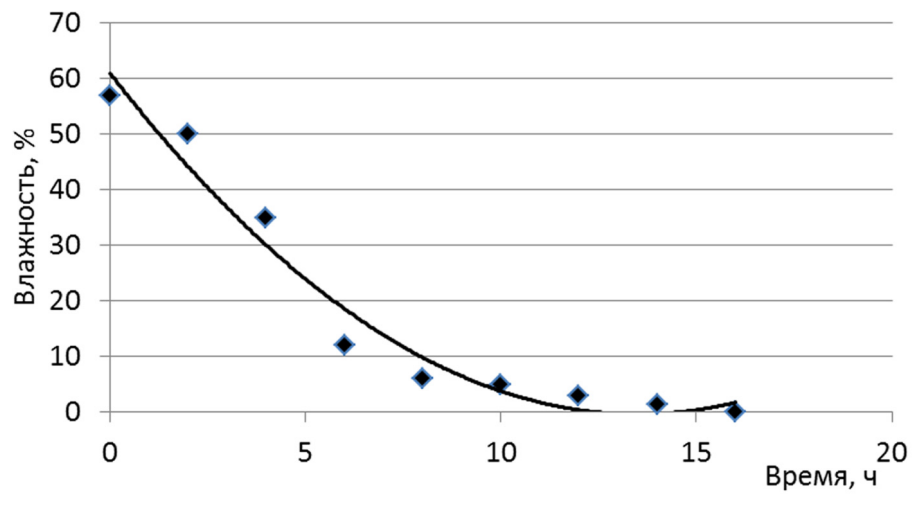

a

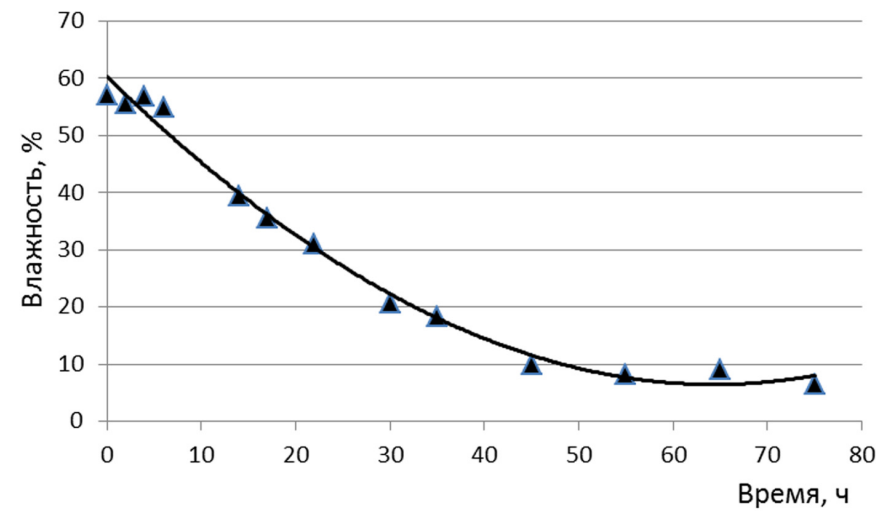

6

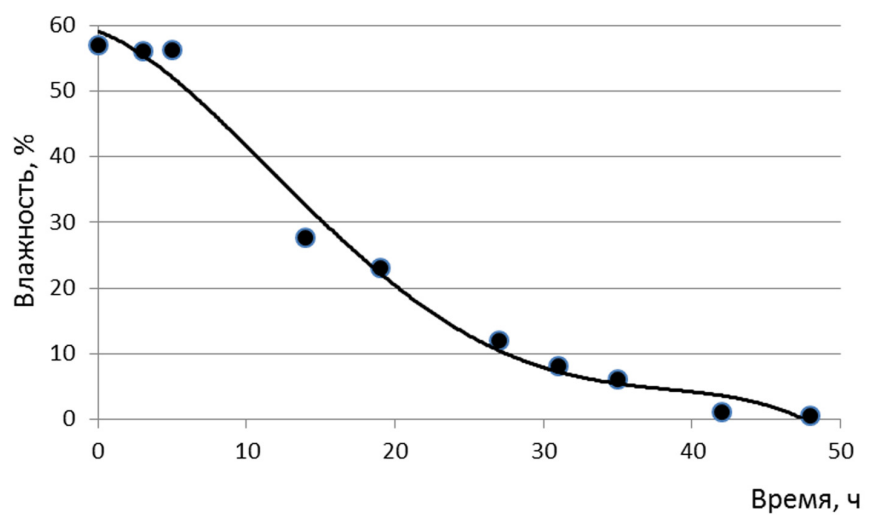

B

Рис. 1. Кривые сушки бактериальной биомассы: $\mathrm{a}-105^{\circ} \mathrm{C} ; 6-60{ }^{\circ} \mathrm{C}$; в - сублимационная сушка 
Таблица 1. Выход продуктов экстракции из бактериальной биомассы, высушенной при различных температурных режимах

\begin{tabular}{|c|c|c|c|}
\hline Наименование & $\begin{array}{l}\text { Липиды и жирные } \\
\text { кислоты, \% от с.б. }\end{array}$ & $\begin{array}{c}\text { Выход полимера, \% } \\
\text { от исходного } \\
\text { содержания в биомассе }\end{array}$ & Чистота полимера, \% \\
\hline Сырая биомасса & $2,55 \pm 0,11$ & $78,7 \pm 3,1$ & $99,7 \pm 0,1$ \\
\hline $\begin{array}{l}\text { Биомасса, высушенная } \\
\text { при } 60^{\circ} \mathrm{C}\end{array}$ & $3,21 \pm 0,15$ & $85,3 \pm 3,7$ & $98,9 \pm 0,2$ \\
\hline $\begin{array}{l}\text { Биомасса, высушенная } \\
\text { при } 105^{\circ} \mathrm{C}\end{array}$ & $2,83 \pm 0,15$ & $24,9 \pm 1,2$ & $99,3 \pm 0,2$ \\
\hline $\begin{array}{l}\text { Сублимационно- } \\
\text { высушенная биомасса }\end{array}$ & $2,42 \pm 0,11$ & $95,5 \pm 4,0$ & $99,9 \pm 0,1$ \\
\hline
\end{tabular}

точные мембраны суммируется и становится критическим, приводит к более полному их разрушению. Отсутствие воды в системе также способствует увеличению выхода полимера.

Значительно меньший выход полимера получен из биомассы, высушенной при $105^{\circ} \mathrm{C}$. Причиной низкого выхода является деструктивное воздействие свободных радикалов, образующихся при денатурации белков, углеводов, пептидов и других соединений, а также возрастающее окисление кислородом (Bugnicourt et al., 2014).

В табл. 2 приведены молекулярномассовые характеристики выделенных образцов полимеров. Образцы, выделенные из биомассы, высушенной при повышенных температурах, имели более низкие показатели, отличающиеся в 2-4 раза от образцов, выделенных из сырой биомассы $\left(\mathrm{M}_{4} 232\right.$ кДа и $\mathrm{M}_{\text {в }} 951$ кДа). Наиболее выраженное снижение молекулярной массы наблюдали у полимера, выделенного из биомассы, высушенной при $105{ }^{\circ} \mathrm{C}$. Так, значения среднечисловой и средневесовой молекулярных масс составили 53 и 238 кДа соответственно. Значительное снижение молекулярной массы образцов, так же как и низкий выход полимера, свидетельствует о его деструкции. При этом показано, что чем выше температура суш- ки, тем ниже значение молекулярной массы полимера. Использование сублимационной сушки бактериальной биомассы не привело к изменению молекулярно-массовых характеристик полимера.

Со снижением молекулярно-массовых показателей изменяются и температурные характеристики полимера (табл. 2 и рис. 2). У образцов, подвергнутых воздействию высоких температур, зафиксировано два пика в области температуры плавления вследствие разделения образца по молекулярной массе. При этом фракция полимера с меньшим значением $\mathrm{M}_{\mathrm{B}}$ имела меньшую температуру плавления.

Температура кристаллизации полимера, выделенного из сырой биомассы, составила $99^{\circ} \mathrm{C}$. Пик имел правильную форму и чёткие границы, что позволяет предполагать образование крупных кристаллических структур в полимере в процессе кристаллизации. У низкомолекулярных образцов температура кристаллизации составила 81,7 и $58,3{ }^{\circ} \mathrm{C}$ соответственно. У обоих образцов пик кристаллизации имел неправильную форму с широкими границами эффекта. Это может свидетельствовать об образовании кристаллитов различного размера, а также о возможных дефектах кристаллической решётки. Температура термической деградации у всех выделенных 
Таблица 2. Физико-химические свойства полученных образцов полимера

\begin{tabular}{|c|c|c|c|c|c|c|}
\hline Наименование & $\mathrm{M}_{ч}$, кДа & $\mathrm{M}_{\mathrm{B}}$, кДа & ПД & $\mathrm{T}_{\text {крист, }},{ }^{\circ} \mathrm{C}$ & $\mathrm{T}_{\text {плл }},{ }^{\circ} \mathrm{C}$ & $\mathrm{T}_{\text {дегр }},{ }^{\circ} \mathrm{C}$ \\
\hline Сырая биомасса, влажность 57 \% & 232 & 951 & 4,1 & 99,0 & 173,1 & 280,8 \\
\hline Биомасса, высушенная при $60^{\circ} \mathrm{C}$ & 115 & 357 & 3,1 & 81,7 & $\begin{array}{l}161,5 \\
171,2\end{array}$ & 284,1 \\
\hline Биомасса, высушенная при $105^{\circ} \mathrm{C}$ & 53 & 238 & 4,5 & 58,3 & $\begin{array}{c}152,8 \\
165,1\end{array}$ & 283,6 \\
\hline $\begin{array}{l}\text { Сублимационно высушенная } \\
\text { биомасса }\end{array}$ & 213 & 961 & 4,5 & 97,2 & 174,2 & 284,4 \\
\hline
\end{tabular}

Примечание: $\mathrm{M}_{4}$ - среднечисловая молекулярная масса, $\mathrm{M}_{\mathrm{B}}$ - средневесовая молекулярная масса, ПД полидисперсность, $\mathrm{T}_{\text {крист }}$ - температура кристаллизации, $\mathrm{T}_{\text {пл }}$ - температура плавления, $\mathrm{T}_{\text {дегр }}$ - температура термической деградации.

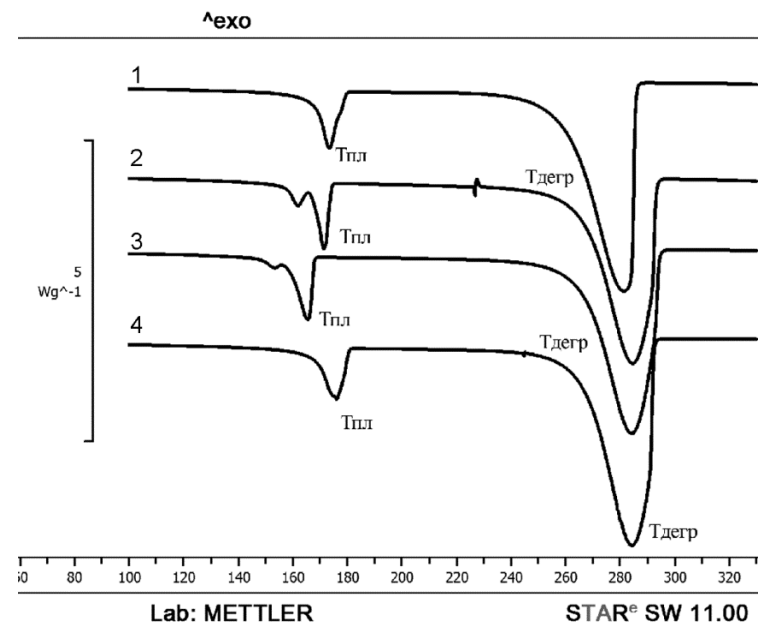

a

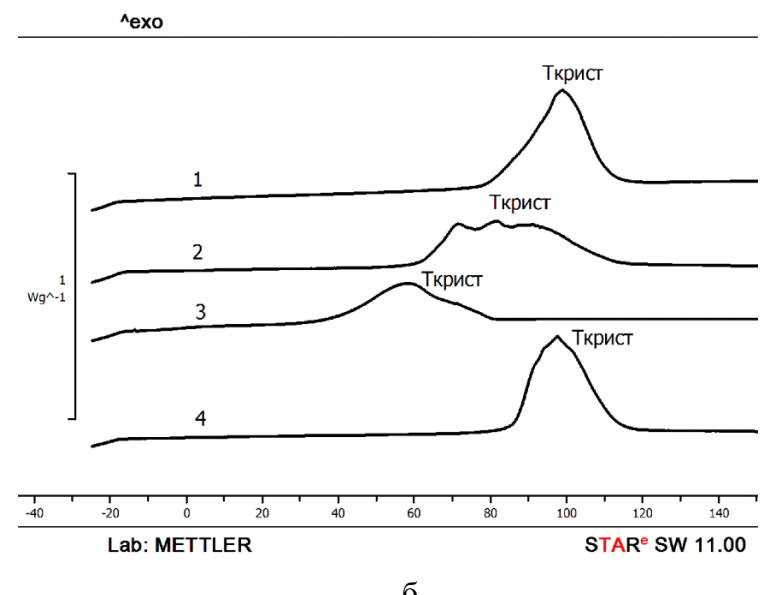

6

Рис. 2. Температурные характеристики полимера: а - температуры плавления и термической деградации; б - температура кристаллизации; 1 - полимер, выделенный из сырой биомассы; 2 - полимер, выделенный из биомассы, высушенной при $60{ }^{\circ} \mathrm{C} ; 3$ - полимер, выделенный из биомассы, высушенной при $105^{\circ} \mathrm{C} ; 4$-полимер, выделенный из сублимационно высушенной биомассы 
образцов полимера не изменилась и находилась в пределах $280-285^{\circ} \mathrm{C}$.

\section{Заключение}

Установлено, что высокотемпературная сушка биомассы бактерий негативно сказывается на полноте экстракции и качественных характеристиках полимера. В результате протекающих процессов деструкции снижаются молекулярно-массовые и температурные характеристики. С увеличением температуры высушивания биомассы скорость и степень деструкции возрастают. Использование сублимационного высушивания биомассы минимизирует негативное воздействие на качественные характеристики полимера и обеспечивает наиболее полную экстракцию, не требуя при этом измельчения биомассы, необходимого для образцов, высушенных при тепловой сушке.

Наработка образцов биомассы за счет средств государственного задания на проведение фундаментальных исследований РАН (проект № гос. регистрации 01201351505); исследование влияния температуры на полноту экстракции и физико-химические свойства при поддержкке гранта Красноярского краевого фонда науки (дополнительное соглашение № 50/15 om 19.06.2015 2. к соглашению № 7 от 06.08.2009 г.).

\section{Список литературы}

Ашмарин И.П., Васильев Н.Н., Амбросов В.А. (1971) Быстрые методы статистической обработки и планирования экспериментов. Л., Изд-во Ленинградского университета, 78 c. [Ashmarin I.P., Vasilev N.N., Abrosimov V.A. (1971) Quick statistical treatment and design of experiments. Leningrad, Leningrad University, 78 p. (in Russian)]

Бергельсон Л.Д. (1975) Биологические мембраны: факты и гипотезы. М., Наука, 182 с. [Bergelson L.D. (1975) Biological membranes: facts and hypotheses. Moscow, Nauka, 182 p. (in Russian)]

Войнов Н.А., Волова Т.Г., Зобова Н.В., Маркова С.В., Франк Л.А., Шишацкая Е.И. (2009) Современные проблемы и методы биотехнологии. Красноярск, Электронное учебное пособие ИПК СФУ, 418 с. [Voinov N.A., Volova T.G., Zobova N.V., Markova S.V., Frank L.A., Shishatskaya E.I. (2009) Modern problems and methods of biotechnology. Krasnoyarsk, Electronic textbook IPK SFU, 418 p. (in Russian)]

Киселев Е.Г., Демиденко А.В. (2014) Сравнительное исследование методов экстракции ПГА из биомассы бактерий. Журнал Сибирского федерального университета. Биология, 7 (2): $148-$ 160 [Kiselev E.G., Demchenko A.V. (2014) A comparative study of extraction methods of PHAs from bacterial biomass. Journal of Siberian Federal University. Biology [Zhurnal Sibirskogo federalnogo universiteta. Biologiya], 7 (2): 148-160 (in Russian)]

Кунилова Т.М. (2008) Анализ существующих типов оборудования и технологий сушки. Проиессы и апnараты пищеевых производств, электронный журнал. Санкт-Петербург, СПбГУНиПТ, 1 [Kunilova T.M. (2008) Analysis of the existing types of drying equipment and techniques. Processes and devices of food manufactures, e-zine. St. Petersburg, SPbGUNiPT, 1 (in Russian)]

Харчук И.А. (2005) Анабиоз: основные понятия и сопровождающие его процессы. Экология моря, 70: 62 - 78 [Kharchuk I.A. (2005) Cryostasis: basic concepts and the accompanying processes. Sea Ecology [Ekologiya morya], 70: 62 - 78 (in Russian)] 
Beker M.J., Blumberg J.E., Ventina E.J., Rapoport A.J. (1984) Characteristics of cellular membranes of rehydration of dehydrated yeast Saccharomyces cerevisiae. Applied Microbiology and Biotechnology, 19: 347-352

Bugnicourt E., Cinelli P., Lazzeri A., Alvarez V. (2014) Polyhydroxyalkanoate (PHA): Review of synthesis, characteristics, processing and potential applications in packaging. eXPRESS Polymer Letters, 8: 791-808

Choi J., Lee S.Y. (1999a) Factors affecting the economics of polyhydroxyalkanoate production by bacterial fermentation. Applied Microbiology and Biotechnology, 51: 13-21

Choi J., Lee S.Y. (1999b) Efficient and economical recovery of poly-(3-hydroxybutyrate) from recombinant Escherichia coli by simple digestion with chemicals. Biotechnology Bioengineering, 62: $546-553$

Gulik-Krzywicki T. (1975) Structural studies of the associations between biological membrane components. Biochimica et Biophysica Acta, 415: 1-28

Krallish I.L., Danberga B.E., Beker M.J. (1986) The effect of yeast degydration on the activity of a number of enzymes of cell energetic metabolism. Applied Microbiology and Biotechnology, 23: $482-486$

Li Y., Naghdi F.G., Garg S., Adarme-Vega T.C., Thurecht K.J., Ghafor W.A., Tannock S., Schenk P.M. (2014) A comparative study: the impact of different lipid extraction methods on current microalgal lipid research. Microbial Cell Factories, 13: 14

Mantelatto P.E., Nazareno A., Sertori D. (2013) US Patent 8357508 B2. Process for extracting and recovering polyhydroxyalkanoates (PHAs) from cellular biomass.

Perelman A., Matsukawa R., Schlosberg M., Cohen B.-S., Fostik-Magyar C., Dubinsky Z. (1998) Natural antioxidant activity in some microalgal species. Israel Journal of Plant Sciences, 46: 169-176

Potts M. (1994) Desiccation tolerance of prokaryotes. Microbiological Reviews, 58: 755-805

Singh S.C., Sinha R.P., Hader D.P. (2002) Role of lipids and fatty acids in stress tolerance in cyanobacteria. Acta Protozoologica, 41: 297-308

Thakor N., Lütke-Eversloh T., Steinbüchel A. (2005) Application of the BPEC pathway for largescale biotechnological production of poly(3-mercaptopropionate) by recombinant Escherichia coli, including a novel in situ isolation method. Applied Environmental Microbiology, 71: 835-841

Zhila N.O., Kalacheva G.S., Volova T.G. (2015) Fatty acid composition and polyhydroxyalkanoates production by Cupriavidus eutrophus B-10646 cells grown on different carbon sources. Process Biochemistry, 50: 69-78 